\title{
HMGB1 overexpression as a prognostic factor for survival in cancer: a meta-analysis and systematic review
}

\author{
Tengyun Wu ${ }^{1, *}$, Wei Zhang ${ }^{2, *}$, Geliang Yang ${ }^{3, *}$, Huijun Li ${ }^{4}$, Qi Chen ${ }^{5}$, Ruixiang Song ${ }^{2}$, \\ Lin Zhao' \\ ${ }^{1}$ Air Force General Hospital of Chinese People's Liberation Army, Beijing 100142, China \\ ${ }^{2}$ Department of Urology, Changhai Hospital, Second Military Medical University, Shanghai 200433, China \\ ${ }^{3}$ Department of Integrated Oncology, Changhai Hospital, Second Military Medical University, Shanghai 200433, China \\ ${ }^{4}$ The Wright Center, Scranton, Pennsylvania 18510, USA \\ ${ }^{5}$ Department of Health Statistics, Faculty of Health Service, Second Military Medical University, Shanghai 200433, China \\ *These authors have contributed equally to this work
}

Correspondence to: Tengyun Wu, email: frost.wty@hotmail.com

Keywords: high mobility group box 1, cancer, survival, prognosis factor, meta-analysis

Received: November 29, $2015 \quad$ Accepted: June 12, $2016 \quad$ Published: July 06, 2016

\section{ABSTRACT}

As there are millions of cancer deaths every year, it is of great value to identify applicable prognostic biomarkers. As an important alarm, the prognostic role of high mobility group box 1 (HMGB1) in cancer remains controversial. We aim to assess the association of HMGB1 expression with prognosis in cancer patients. Systematic literature searches of PubMed, Embase and Web of Science databases were performed for eligible studies of HMGB1 as prognostic factor in cancer. Pooled hazard ratios (HRs) and $\mathbf{9 5 \%}$ confidence intervals (CIs) were calculated to evaluate the influence of HMGB1 expression on overall survival (OS) and progression-free survival (PFS) in cancer patients. 18 studies involving 11 different tumor types were included in meta-analysis. HMGB1 overexpression was significantly associated with poorer OS (HR: 1.99; 95\% CI, 1.71-2.31) and PFS (HR: 2.26; 95\% CI, 1.65-3.10) irrespective of cancer types including gastric cancer, colorectal cancer, hepatocellular carcinoma, pancreatic cancer, nasopharyngeal carcinoma, head and neck squamouscell carcinoma, esophageal cancer, malignant pleural mesothelioma, bladder cancer, prostate cancer, and cervical carcinoma. Subgroup analyses indicated geographical area and size of studies did not affect the prognostic effects of HMGB1 for OS. Morever, HMGB1 overexpression had a consistent correlation with poorer OS when detected by immunohistochemistry in tissues and enzyme-linked immunosorbent assay in serum, whereas the correlation did not exist by quantitative real-time reverse-transcription polymerase chain reaction in tissues. HMGB1 overexpression is associated with poorer prognosis in patients with various types of cancer, suggesting that it is a prognostic factor and potential biomarker for survival in cancer.

\section{INTRODUCTION}

According to the reports from $\mathrm{WHO}$, there were 14.1 million new cancer cases, 8.2 million cancer deaths and 32.6 million people living with cancer (within 5 years of diagnosis) in 2012 worldwide [1]. Combination of surgery, radiotherapy and chemotherapy remains the standard treatment in most cancer cases, however, not all patients derive benefit from it [2]. In addition, more and more targeted agents and biotherapies are now available while the applicable patients are limited [3]. Therefore, it is critical to identify applicable prognostic biomarkers, guiding individualized treatment and improving unfavorable prognosis.

High mobility group box 1 (HMGB1) protein, which was discovered in calf thymus in 1973 [4], is a ubiquitous chromatin component expressed in nucleated mammalian cells. In 1990s', Wang’s work demonstrated 
that HMGB1 is involved in the pathological process of sepsis for the first time [5]. Now we have known that HMGB1 was involved in transcription regulation of many cancer genes, including E-selectin, TNF- $\alpha$, BRCA1 and insulin receptor [6-9]. In addition to these reports, recent evidence demonstrates that HMGB1 plays an important role in the tumorigenesis and progression of many types of cancers such as digestive system, urogenital system, skin, bone, and blood cancer [10-12]. However, HMGB1 acts as both a tumor suppressor and an oncogenic factor in tumorigenesis and cancer therapy depending on the context and HMGB1 location and modification [13]. The prognostic value of HMGB1 overexpression for survival across different tumors still remains controversial. Therefore, we performed a literature-based systematic review and meta-analysis in order to assess the association of HMGB1 expression with prognosis in patients with cancer.

\section{RESULTS}

\section{Study characteristics}

18 studies met our inclusion criteria and were finally included for the analysis, involving 11 different tumor types (3 studies of gastric cancer [14-16], 4 of colorectal cancer [17-20], 2 of hepatocellular carcinoma [21, 22], 2 of pancreatic cancer [23, 24], 1 of nasopharyngeal carcinoma [25], 1 of head and neck squamous-cell carcinoma [26], 1 of esophageal cancer [27], 1 of malignant pleural mesothelioma [28], 1 of bladder cancer [29], 1 of prostate cancer [30], and 1 of cervical carcinoma [31]) (Figure 1). A total of 2249 participants were analyzed for the association between HMGB1 expression and disease prognosis, of which 2090 (92.9\%) and $1247(55.4 \%)$ ones were respectively included into overall survival (OS) and progression-free survival (PFS) analyses. The detailed information of included studies was summarized in Table 1.

Among 18 studies, 15 were prospective cohort researches (level of evidence: 1b) whereas 3 were retrospective designs (level of evidence: $2 \mathrm{~b}$ ). The methodological quality of included studies was relatively high for 17 cohorts (NOS: 7 of 9 points and 6 of 9 points) and medium for one (NOS: 5 of 9 points), which was mainly attributed to the lack of definite follow-up period and lost rate. According to the guidelines for assessing quality in prognostic studies, the evaluation results of each item with potential bias were presented as "yes", "partly", "no" or "unsure" in Table 2. The key baseline characteristics of patients were adequately presented and the adopted statistical analyses were appropriate in all included studies. However, study by Soldevilla et al [19] did not give a well-defined interpretation standard of HMGB1 expression. In addition, the duration of follow-up was not distinctly described in 4 studies of Akaike et al [14], He et al [15], Wittwer et al [24] and Sheng et al [31]. Unfortunately, there was no study mentioning important confounders like the subsequent treatment. The evaluation standards of HMGB1 expression and group definitions of HMGB1 high/positive or low/negative in included studies were summarized in Supplementary Table S1.

\section{HMGB1 and OS}

In all, 17 studies included data on OS in 10 types of cancer. Homogeneity tests showed evidence of nonsignificant heterogeneity among studies in all the OS analyses except for the subgroup detected by quantitative real-time reverse-transcription polymerase chain reaction (qRT-PCR) in tissues. HMGB1 overexpression was significantly associated with a poorer OS in patients with

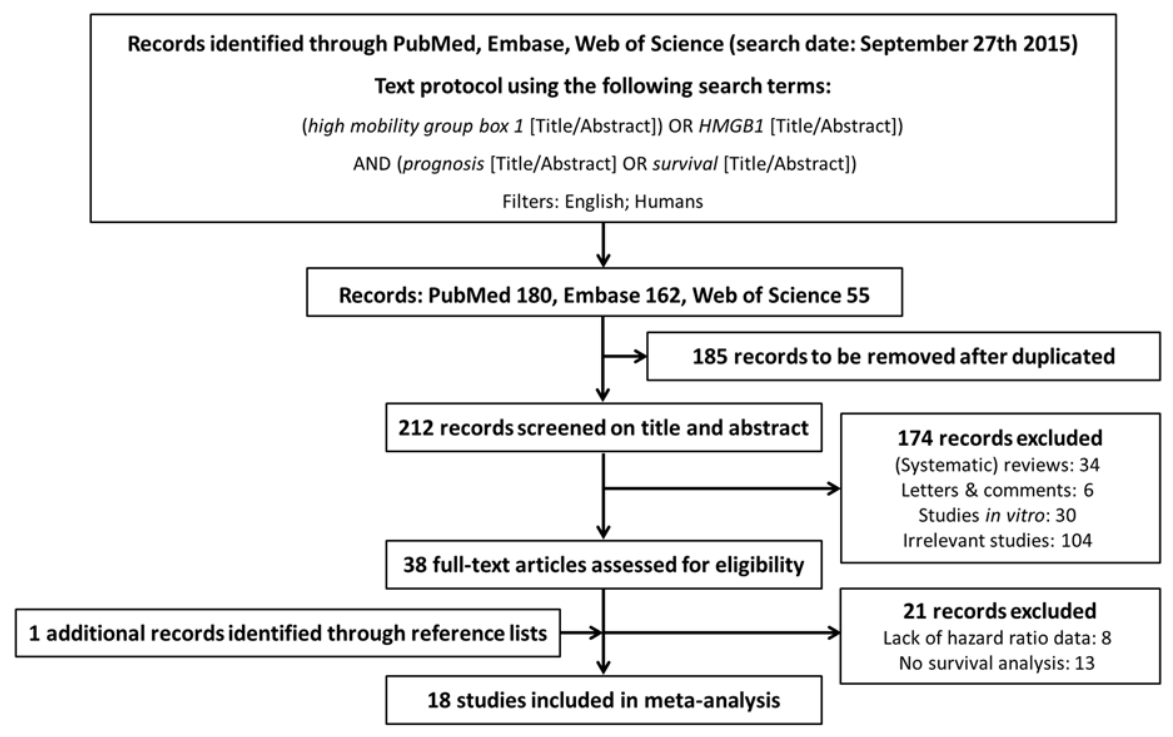

Figure 1: Flow diagram of search strategy. 
Table 1: Summary of 11 types of cancer studies included in the meta-analysis

\begin{tabular}{|c|c|c|c|c|c|c|c|}
\hline \multirow[t]{2}{*}{ Cancer type } & \multirow[t]{2}{*}{ Study } & \multirow[t]{2}{*}{ Institution (Country) } & \multirow{2}{*}{$\begin{array}{l}\text { Study } \\
\text { period }\end{array}$} & \multirow{2}{*}{$\begin{array}{l}\text { Specimen } \\
\text { source }\end{array}$} & \multirow{2}{*}{$\begin{array}{c}\text { Detection } \\
\text { method }\end{array}$} & \multicolumn{2}{|c|}{ Cases, $\mathbf{n}$} \\
\hline & & & & & & $\begin{array}{l}\text { HMGB1 high/ } \\
\text { positive }\end{array}$ & $\begin{array}{c}\text { HMGB1 low/ } \\
\text { negative }\end{array}$ \\
\hline \multirow[t]{4}{*}{ gastric cancer } & Akaike et al & University of Yamanashi (Japan) & $1997-1998$ & tissue & $\mathrm{IHC}$ & 35 & 41 \\
\hline & He et al & $\begin{array}{l}\text { The first Affiliated Hospital of Sun } \\
\text { Yat-Sen University (China) }\end{array}$ & 2003-2005 & tissue & $\mathrm{IHC}$ & 56 & 83 \\
\hline & Zhang et al & $\begin{array}{l}\text { Shanghai Sixth People's Hospital, } \\
\text { Shanghai Jiaotong University (China) }\end{array}$ & 2007-2011 & tissue & $\mathrm{IHC}$ & 32 & 18 \\
\hline & Yao et al & $\begin{array}{c}\text { The First Affiliated Hospital of Jilin } \\
\text { University (China) }\end{array}$ & 2002-2006 & tissue & $\mathrm{IHC}$ & 107 & 85 \\
\hline \multirow[t]{3}{*}{$\begin{array}{l}\text { colorectal } \\
\text { cancer }\end{array}$} & Peng et al & $\begin{array}{c}\text { Cancer Center of Sun Yat-Sen } \\
\text { University (China) }\end{array}$ & 1999-2002 & tissue & $\mathrm{IHC}$ & 40 & 32 \\
\hline & Soldevilla et al & $\begin{array}{l}\text { Puerta de Hierro Majadahonda } \\
\text { University Hospital (Spain) }\end{array}$ & 2001-2003 & tissue & qRT-PCR & 51 & 26 \\
\hline & Ueda et al & $\begin{array}{c}\text { Kyushu University Beppu Hospital } \\
\text { (Japan) }\end{array}$ & 1992-2002 & tissue & qRT-PCR & 70 & 70 \\
\hline \multirow[t]{2}{*}{$\begin{array}{l}\text { hepatocellular } \\
\text { carcinoma }\end{array}$} & Liu et al & $\begin{array}{c}\text { Cancer Center of Sun Yat-Sen } \\
\text { University (China) }\end{array}$ & 2004-2005 & tissue & $\mathrm{IHC}$ & 69 & 92 \\
\hline & Xiao et al & $\begin{array}{l}\text { General Hospital of Guangzhou } \\
\text { Military Command of PLA (China) }\end{array}$ & 1999-2002 & tissue & $\mathrm{IHC}$ & 134 & 74 \\
\hline \multirow[t]{2}{*}{$\begin{array}{l}\text { pancreatic } \\
\text { cancer }\end{array}$} & Chung et al & $\begin{array}{c}\text { Yonsei University College of } \\
\text { Medicine (Korea) }\end{array}$ & 2006-2011 & serum & ELISA & 33 & 12 \\
\hline & Wittwer et al & $\begin{array}{l}\text { University Hospital Munich- } \\
\text { Grosshadern (Germany) }\end{array}$ & $2006-2010$ & serum & ELISA & NA & NA \\
\hline $\begin{array}{l}\text { nasopharyngeal } \\
\text { carcinoma }\end{array}$ & Wu et al & $\begin{array}{c}\text { Nanfang Hospital, Southern Medical } \\
\text { University (China) }\end{array}$ & $1998-2002$ & tissue & $\mathrm{IHC}$ & 89 & 77 \\
\hline $\begin{array}{l}\text { squamous-cell } \\
\text { carcinoma of } \\
\text { the head and } \\
\text { neck }\end{array}$ & Liu et al & $\begin{array}{c}\text { Xiangya Hospital, Central South } \\
\text { University (China) }\end{array}$ & 2002-2004 & tissue & $\mathrm{IHC}$ & 45 & 58 \\
\hline $\begin{array}{l}\text { esophageal } \\
\text { cancer }\end{array}$ & Chuangui et al & $\begin{array}{l}\text { Tianjin Medical University Cancer } \\
\text { Institute and Hospital (China) }\end{array}$ & 2001-2003 & tissue & $\mathrm{IHC}$ & 50 & 22 \\
\hline $\begin{array}{l}\text { malignant } \\
\text { pleural } \\
\text { mesothelioma }\end{array}$ & Tabata et al & $\begin{array}{l}\text { Hyogo College of Medicine Hospital } \\
\text { (Japan) }\end{array}$ & 2005-2009 & serum & ELISA & NA & NA \\
\hline bladder cancer & Yang et al & $\begin{array}{c}\text { Renji Hospital, Shanghai Jiao Tong } \\
\text { University (China) }\end{array}$ & 2003-2005 & tissue & $\mathrm{IHC}$ & 87 & 77 \\
\hline prostate cancer & Li et al & $\begin{array}{l}\text { Tongji Hospital, Tongji University } \\
\text { (China) }\end{array}$ & $2002-2010$ & tissue & $\mathrm{IHC}$ & 95 & 64 \\
\hline $\begin{array}{l}\text { cervical } \\
\text { carcinoma }\end{array}$ & Sheng et al & $\begin{array}{c}\text { Shandong Cancer Hospital and } \\
\text { Institution (China) }\end{array}$ & 2000-2008 & serum & ELISA & NA & NA \\
\hline
\end{tabular}

IHC: immunohistochemistry; qRT-PCR: quantitative real-time polymerase chain reaction; ELISA: enzyme-linked immunosorbent assay; HMGB1: highmobility group box 1 .

cancer (HR: 1.99; 95\% CI, 1.71-2.31). Furthermore, the statistical significance was constant irrespective of different tumor types containing gastric cancer (HR: 2.30 ; 95\% CI, 1.16-4.57), colorectal cancer (HR: $1.54 ; 95 \%$ CI, 1.17-2.04), hepatocellular carcinoma (HR: $1.80 ; 95 \%$ CI, 1.35-2.40), pancreatic cancer (HR: 2.61; $95 \% \mathrm{CI}$, 1.48-4.59), nasopharyngeal carcinoma (HR: $2.80 ; 95 \%$ CI, 1.37-5.73), head and neck squamous-cell carcinoma
(HR: 2.13; 95\% CI, 1.08-4.22), esophageal cancer (HR: 2.28; 95\% CI, 1.41-3.64), malignant pleural mesothelioma (HR: 2.10; 95\% CI, 1.00-4.40), bladder cancer (HR: 4.31; 95\% CI, 2.21-8.41), and cervical carcinoma (HR: 2.12; 95\% CI, 1.09-4.53) (Figure 2).

Subgroup analyses were carried out according to specimen source and detection method, geographical area, and size of studies. In these 17 studies, HMGB1 
Table 2: Quality assessment of the studies included in the meta-analysis

\begin{tabular}{lcccccccc}
\hline Study & \multicolumn{2}{c}{ Quality evaluation of prognosis study } & Study & $\begin{array}{c}\text { Level of } \\
\text { evidence }\end{array}$ \\
\cline { 2 - 6 } & $\begin{array}{c}\text { Study } \\
\text { participation }\end{array}$ & $\begin{array}{c}\text { Study } \\
\text { attrition }\end{array}$ & $\begin{array}{c}\text { Prognostic } \\
\text { factor } \\
\text { measurement }\end{array}$ & $\begin{array}{c}\text { Outcome } \\
\text { measurement }\end{array}$ & $\begin{array}{c}\text { Confounding } \\
\text { measurement } \\
\text { and account }\end{array}$ & Analysis & & \\
\hline Akaike et al & Yes & Yes & Yes & Partly & Partly & Yes & 6 & $1 \mathrm{~b}$ \\
He et al & Yes & Yes & Yes & Partly & Partly & Yes & 6 & $1 \mathrm{~b}$ \\
Zhang et al & Yes & Yes & Yes & Yes & Partly & Yes & 7 & $1 \mathrm{~b}$ \\
Yao et al & Yes & Yes & Yes & Yes & Partly & Yes & 7 & $1 \mathrm{~b}$ \\
Peng et al & Yes & Yes & Yes & Yes & Partly & Yes & 7 & $1 \mathrm{~b}$ \\
Soldevilla et al & Yes & Yes & Partly & Yes & Partly & Yes & 7 & $1 \mathrm{~b}$ \\
Ueda et al & Yes & Yes & Yes & Yes & Partly & Yes & 6 & $1 \mathrm{~b}$ \\
Liu et al & Yes & Yes & Yes & Yes & Partly & Yes & 7 & $1 \mathrm{~b}$ \\
Xiao et al & Yes & Yes & Yes & Yes & Partly & Yes & 6 & $1 \mathrm{~b}$ \\
Chung et al & Yes & Yes & Yes & Yes & Partly & Yes & 7 & $1 \mathrm{~b}$ \\
Wittwer et al & Yes & Yes & Yes & Partly & Partly & Yes & 6 & $1 \mathrm{~b}$ \\
Wu et al & Yes & Yes & Yes & Yes & Partly & Yes & 7 & $1 \mathrm{~b}$ \\
Liu et al & Yes & Yes & Yes & Yes & Partly & Yes & 7 & $2 \mathrm{~b}$ \\
Chuangui et al & Yes & Yes & Yes & Yes & Partly & Yes & 5 & $2 \mathrm{~b}$ \\
Tabata et al & Yes & Yes & Yes & Yes & Partly & Yes & 7 & $1 \mathrm{~b}$ \\
Yang et al & Yes & Yes & Yes & Yes & Partly & Yes & 6 & $2 \mathrm{~b}$ \\
Li et al & Yes & Yes & Yes & Yes & Partly & Yes & 7 & $1 \mathrm{~b}$ \\
Sheng et al & Yes & Yes & Yes & Partly & Partly & Yes & 6 & $1 \mathrm{~b}$ \\
\hline
\end{tabular}

was respectively detected using immunohistochemistry (IHC) staining and qRT-PCR in cancer tissues by 11 and 2 researches, and the remaining 4 investigations evaluated the expression of serum HMGB1 using enzyme-linked immunosorbent assay (ELISA). Different from the other two practice of IHC in tissues (HR: 1.95; 95\% CI, 1.642.31) and ELISA in serum (HR: 2.32; 95\% CI, 1.59-3.40), HMGB1 expression had no correlation with the OS of patients when detected by qRT-PCR in tissues (HR: 2.71; 95\% CI, 0.73-10.02) (Figure 3). Geographically, 15 studies were conducted in Asia (11 in China, 3 in Japan and 1 in Korea) and the remaining 2 in Europe ( 1 in Spain and 1 in Germany). The OS was significantly shorter in patients with high HMGB1 expression compared those with low HMGB1 expression in both Asia (HR: 1.94; 95\% CI, 1.67-2.26) and Europe (HR: 2.93; 95\% CI, 1.58-5.43) (Figure 4). The sample size of included studies ranged from 45 to 286 , and 9 ones enrolled more than 100 participants each. Whatever, the HRs for OS were similar between the subgroups with $<100$ patients (HR: 2.06; 95\% CI, 1.57-2.69) and $\geq 100$ patients (HR: 1.96; 95\% CI, 1.64-2.34) (Figure 5).

\section{HMGB1 and PFS}

There were 7 studies reporting data on PFS in 6 types of cancer altogether. Homogeneity test indicated the heterogeneity among studies so the random-effects model was used. The pooled estimate showed a significant shorter PFS in cancer patients with HMGB1 overexpression (HR: 2.26; 95\% CI, 1.65-3.10). In addition, the effects of HMGB1 overexpression on PFS were consistent among different tumor types: hepatocellular carcinoma (HR: $1.63 ; 95 \%$ CI, 1.24-2.14), nasopharyngeal carcinoma (HR: 1.94; 95\% CI, 1.10-3.43), head and neck squamous-cell carcinoma (HR: 2.12; 95\% CI, 1.19-3.78), bladder cancer (HR: 5.27; 95\% CI, 2.99-9.28), prostate cancer (HR: 2.35; 95\% CI, 1.37-6.36), and cervical carcinoma (HR: 2.93; 95\% CI, 1.45-6.33) (Figure 6).

\section{DISCUSSION}

The traditional assessment of prognosis in patients with cancer is mostly based on the tumor type, 
pathological grading, and clinical stage. However, it has been demonstrated that other factors like molecular and cellular characteristics of primary tumor may improve our prognostic evaluation [32], and then guide the development of appropriate surgical treatment strategy as well as the choice of postoperative management. In this article, we conducted a meta-analysis to evaluate
HMGB1 mRNA and protein expression levels in tissue or serum from patients with cancer. The results indicated that HMGB1 overexpression was associated with poorer prognosis in patients with various types of cancer.

The high mobility group (HMG) proteins, a group of non-histone nuclear proteins with high electrophoretic mobility, were first discovered in 1973. This protein

\begin{tabular}{|c|c|c|c|c|}
\hline Cancer type & Study & Weight & Hazard ratio $(95 \% \mathrm{Cl})$ & Hazard ratio $(95 \% \mathrm{Cl})$ \\
\hline \multirow[t]{4}{*}{ Gastric cancer } & Akaike 2007 & $0.4 \%$ & $0.54(0.15-19.61)$ & \\
\hline & He 2013 & $2.7 \%$ & $2.66(1.04-6.32)$ & \\
\hline & Zhang 2014 & $1.6 \%$ & $2.51(0.55-5.78)$ & \\
\hline & Subtotal & $4.7 \%$ & $2.30(1.16-4.57)$ & $\infty$ \\
\hline \multirow[t]{5}{*}{ Colorectal cancer } & Yao 2010 & $12.1 \%$ & $1.56(1.02-2.40)$ & \\
\hline & Peng 2010 & $6.3 \%$ & $1.11(0.61-1.99)$ & \\
\hline & Soldevilla 2011 & $1.2 \%$ & $16.25(.61-24.19)$ & \\
\hline & Ueda 2014 & $9.3 \%$ & $1.59(1.00-2.65)$ & \\
\hline & Subtotal & $29.0 \%$ & $1.54(1.17-2.04)$ & \\
\hline \multirow[t]{3}{*}{ Hepatocellular carcinoma } & Liu 2012 & $10.9 \%$ & $1.83(1.17-2.88)$ & \\
\hline & Xiao 2014 & $16.2 \%$ & $1.78(1.23-2.58)$ & \\
\hline & Subtotal & $27.1 \%$ & $1.80(1.35-2.40)$ & \\
\hline \multirow[t]{3}{*}{ Pancreatic cancer } & Chung 2012 & $2.3 \%$ & $3.08(1.15-8.20)$ & \\
\hline & Wittwer 2013 & $4.6 \%$ & $2.40(1.20-4.80)$ & \\
\hline & Subtotal & $6.9 \%$ & $2.61(1.48-4.59)$ & \\
\hline Nasopharyngeal carcinoma & Wu 2008 & $4.3 \%$ & $2.80(1.37-5.73)$ & \\
\hline $\begin{array}{l}\text { Squamous-cell carcinoma of the } \\
\text { head and neck }\end{array}$ & Liu 2010 & $4.8 \%$ & $2.13(1.08-4.22)$ & \\
\hline Esophageal cancer & Chuangui 2012 & $9.9 \%$ & $2.28(1.41-3.64)$ & \\
\hline Malignant pleural mesothelioma & Tabata 2013 & $4.0 \%$ & $2.10(1.00-4.40)$ & \\
\hline Bladder cancer & Yang 2012 & $5.0 \%$ & $4.31(2.21-8.41)$ & \\
\hline \multirow[t]{3}{*}{ Cervical carcinoma } & Sheng 2009 & $4.4 \%$ & $2.12(1.09-4.53)$ & \\
\hline & Total & $100.0 \%$ & $1.99(1.71-2.31)$ & $\infty$ \\
\hline & & & $T_{0.04}^{1}$ & 1 \\
\hline Heterogeneity: $I^{2}=12 \%, p=0.316$ & & & Favors & positive Favor \\
\hline
\end{tabular}

Figure 2: Forest plot evaluating association of HMGB1 expression and overall survival.

\begin{tabular}{|c|c|c|c|c|}
\hline $\begin{array}{l}\text { Specimen source/ } \\
\text { Detection method }\end{array}$ & Study & Weight & Hazard ratio $(95 \% \mathrm{CI})$ & Hazard ratio $(95 \% \mathrm{Cl})$ \\
\hline \multirow[t]{13}{*}{ Tissue/IHC } & Akaike 2007 & $0.5 \%$ & $0.54(0.15-19.61)$ & \\
\hline & He 2013 & $3.7 \%$ & $2.66(1.04-6.32)$ & \\
\hline & Zhang 2014 & $2.2 \%$ & $2.51(0.55-5.78)$ & \\
\hline & Yao 2010 & $16.3 \%$ & $1.56(1.02-2.40)$ & \\
\hline & Peng 2010 & $8.5 \%$ & $1.11(0.61-1.99)$ & \\
\hline & Liu 2012 & $14.7 \%$ & $1.83(1.17-2.88)$ & \\
\hline & Xiao 2014 & $21.7 \%$ & $1.78(1.23-2.58)$ & \\
\hline & Wu 2008 & $5.8 \%$ & $2.80(1.37-5.73)$ & \\
\hline & Liu 2010 & $6.4 \%$ & $2.13(1.08-4.22)$ & \\
\hline & Chuangui 2012 & $13.6 \%$ & $2.28(1.43-3.64)$ & \\
\hline & Yang 2012 & $6.7 \%$ & $4.31(2.21-8.41)$ & \\
\hline & Subtotal & $100.0 \%$ & $1.95(1.64-2.31)$ & \\
\hline & & \multicolumn{2}{|c|}{ Heterogeneity: $I^{2}=26 \%, p=0.201$} & \\
\hline \multirow[t]{4}{*}{ Tissue/qRT-PCR } & Soldevilla 2011 & $38.9 \%$ & $6.25(1.61-24.19)$ & \\
\hline & Ueda 2014 & $61.1 \%$ & $1.59(1.00-2.65)$ & \\
\hline & Subtotal & $100.0 \%$ & $2.71(0.73-10.02)$ & \\
\hline & & \multicolumn{2}{|c|}{ Heterogeneity: $I^{2}=71 \%, p=0.062$} & \\
\hline \multirow[t]{7}{*}{ Serum/ELISA } & Chung 2012 & $15.0 \%$ & $3.08(1.15-8.20)$ & \\
\hline & Wittwer 2013 & $30.1 \%$ & $2.40(1.20-4.80)$ & \\
\hline & Tabata 2013 & $26.4 \%$ & $2.10(1.00-4.40)$ & \\
\hline & Sheng 2009 & $28.5 \%$ & $2.12(1.09-4.53)$ & \\
\hline & Subtotal & $100.0 \%$ & $2.32(1.59-3.40)$ & \\
\hline & & \multicolumn{2}{|c|}{ Heterogeneity: $I^{2}=0 \%, p=0.928$} & \\
\hline & & & $\begin{array}{l}7 \\
0.04\end{array}$ & 1 \\
\hline
\end{tabular}

Figure 3: Subgroup forest plot evaluating association of HMGB1 expression and overall survival by specimen source and detection method. 
family includes three super families termed HMGB, HMGN, and HMGA [4]. As the most abundant and well-studied HMG protein, HMGB1 is indicated to be associated with ten functional capabilities that drive tumor development and growth [33]. These cancer hallmarks include: sustainment of proliferative signaling; evasion of growth suppressors; avoidance of immune destruction; enablement of replicative immortality; tumor-promoting inflammation; activation of invasion and metastasis; induction of angiogenesis; genome instability and mutation; resistance to cell death; and deregulation of cellular energetics [34]. Meanwhile, higher HMGB1 expression was detected in late stage patients with hepatocellular carcinoma [35] and squamous-cell carcinoma of the head and neck [26]. In this respect, HMGB1 can be considered as an oncoprotein. However, as reviewed by Kang et al [13], HMGB1 can act as both a tumor suppressor and an oncogenic factor in tumorigenesis and cancer therapy according to different experiment conditions.

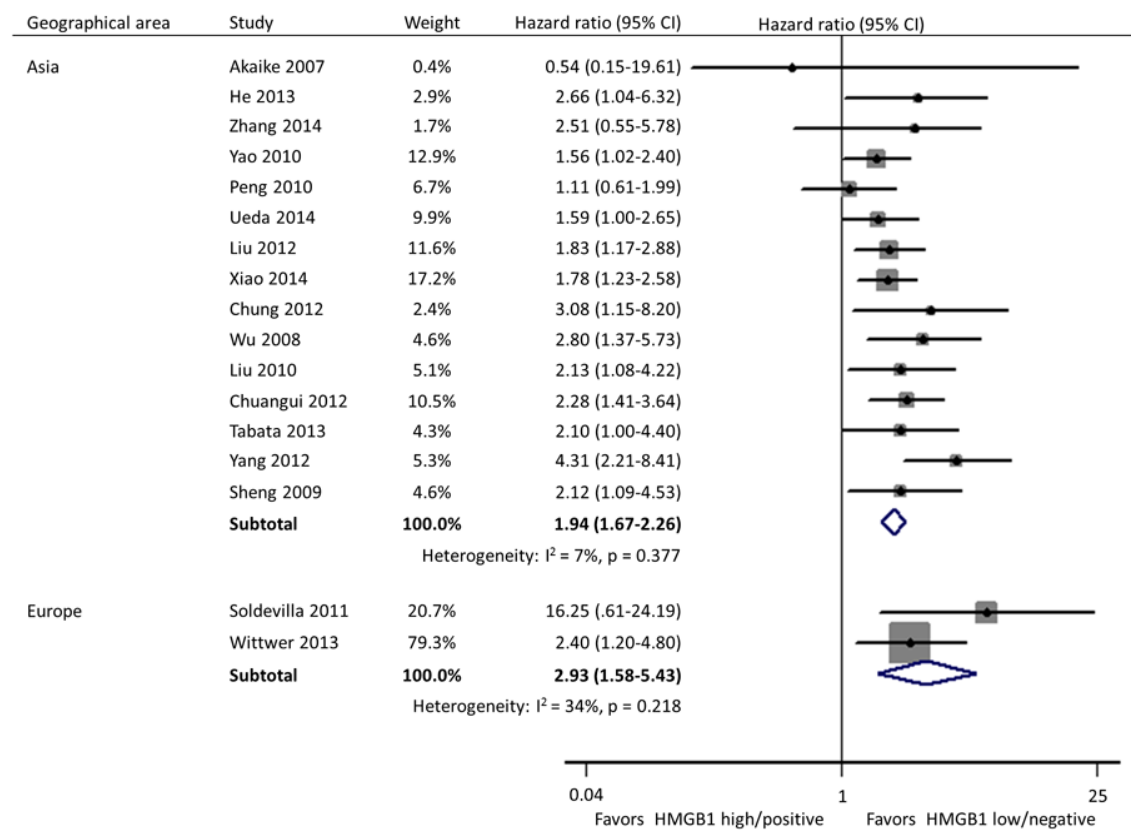

Figure 4: Subgroup forest plot evaluating association of HMGB1 expression and overall survival by geographical area.

\begin{tabular}{|c|c|c|c|c|c|}
\hline Size of studies & Study & Weight & Hazard ratio $(95 \% \mathrm{CI})$ & Hazard ratio $(95 \% \mathrm{Cl})$ & \\
\hline \multirow[t]{10}{*}{$<100$} & Akaike 2007 & $1.2 \%$ & $0.54(0.15-19.61)$ & & \\
\hline & Zhang 2014 & $5.3 \%$ & $2.51(0.55-5.78)$ & & \\
\hline & Peng 2010 & $20.9 \%$ & $1.11(0.61-1.99)$ & & \\
\hline & Soldevilla 2011 & $4.0 \%$ & $6.25(1.61-24.19)$ & & \\
\hline & Chung 2012 & $7.6 \%$ & $3.08(1.15-8.20)$ & & \\
\hline & Wittwer 2013 & $15.2 \%$ & $2.40(1.20-4.80)$ & & \\
\hline & Chuangui 2012 & $32.5 \%$ & $2.28(1.41-3.64)$ & & \\
\hline & Tabata 2013 & $13.3 \%$ & $2.10(1.00-4.40)$ & & \\
\hline & Subtotal & $100.0 \%$ & $2.06(1.57-2.69)$ & & \\
\hline & & \multicolumn{2}{|c|}{ Heterogeneity: $I^{2}=23 \%, p=0.249$} & & \\
\hline \multirow[t]{13}{*}{$\geq 100$} & He 2013 & $3.9 \%$ & $2.66(1.04-6.32)$ & & \\
\hline & Yao 2010 & $17.4 \%$ & $1.56(1.02-2.40)$ & & \\
\hline & Ueda 2014 & $13.4 \%$ & $1.59(1.00-2.65)$ & & \\
\hline & Liu 2012 & $15.7 \%$ & $1.83(1.17-2.88)$ & & \\
\hline & Хiao 2014 & $23.2 \%$ & $1.78(1.23-2.58)$ & & \\
\hline & Wu 2008 & $6.2 \%$ & $2.80(1.37-5.73)$ & & \\
\hline & Liu 2010 & $6.9 \%$ & $2.13(1.08-4.22)$ & & \\
\hline & Yang 2012 & $7.1 \%$ & $4.31(2.21-8.41)$ & & \\
\hline & Sheng 2009 & $6.3 \%$ & $2.12(1.09-4.53)$ & $\rightarrow$ & \\
\hline & Subtotal & $100.0 \%$ & $1.96(1.64-2.34)$ & $>$ & \\
\hline & & \multicolumn{2}{|c|}{ Heterogeneity: $I^{2}=11 \%, p=0.343$} & & \\
\hline & & & 1 & & $T$ \\
\hline & & & 0.04 & 1 & 25 \\
\hline
\end{tabular}

Figure 5: Subgroup forest plot evaluating association of HMGB1 expression and overall survival by size of studies. 


\begin{tabular}{|c|c|c|c|c|c|}
\hline Cancer type & Study & Weight & Hazard ratio $(95 \% \mathrm{Cl})$ & Hazard ratio $(95 \% \mathrm{CI})$ & \\
\hline \multirow[t]{3}{*}{ Hepatocellular carcinoma } & Liu 2012 & $18.2 \%$ & $1.62(1.09-2.42)$ & & \\
\hline & Xiao 2014 & $19.0 \%$ & $1.64(1.13-2.37)$ & & \\
\hline & Subtotal & $37.2 \%$ & $1.63(1.24-2.14)$ & & \\
\hline Nasopharyngeal carcinoma & Wu 2008 & $14.0 \%$ & $1.94(1.10-3.43)$ & & \\
\hline $\begin{array}{l}\text { Squamous-cell carcinoma } \\
\text { of the head and neck }\end{array}$ & Liu 2010 & $13.8 \%$ & $2.12(1.19-3.78)$ & & \\
\hline Bladder cancer & Yang 2012 & $14.1 \%$ & $5.27(2.99-9.28)$ & & \\
\hline Prostate cancer & Li 2012 & $10.2 \%$ & $2.35(1.37-6.36)$ & & \\
\hline \multirow[t]{3}{*}{ Cervical carcinoma } & Sheng 2009 & $10.7 \%$ & $2.93(1.45-6.33)$ & & \\
\hline & Total & $100.0 \%$ & $2.26(1.65-3.10)$ & & \\
\hline & & & $\begin{array}{ll} \\
0.1\end{array}$ & 1 & $\begin{array}{r}1 \\
10\end{array}$ \\
\hline Heterogeneity: $I^{2}=58 \%, p=$ & & & Favors HMGB1 & h/positive Favors & AGB1 low/negative \\
\hline
\end{tabular}

Figure 6: Forest plot evaluating association of HMGB1 expression and progression-free survival.

The underlying mechanisms involved in the relationship between HMGB1 expression and prognosis in patients with cancer are uncertain.

In current meta-analysis, we revealed that HMGB1 overexpression was significantly associated with a poorer OS and a shorter PFS in cancer patients, moreover, the statistical significance was constant irrespective of different tumor types. In 16 included studies, multivariate analysis with the Cox's proportional hazards model was also performed to demonstrate that HMGB1 was an independent prognostic factor for patients with cancer. Besides the overall evaluation, subgroup analyses were done in respect of specimen source and detection method, geographical area, and size of studies. The association of HMGB1 overexpression with survivals persisted and remained statistically significant under all the classification criteria except when the detection method of qRT-PCR in tissues was adopted. On one hand, the limited available studies and their small sample size may contribute to this insignificant. On the other hand, the fact existing is that there is no internationally accepted and validated method for HMGB1 expression assessment so far. Further researches are urged to determine the best detection procedure and then establish the consistent standard.

HMGB1 plays a crucial role not only inside the cell as a chromatin structural protein, but also outside the cell as a cytokine [36]. It can be secreted actively by various cells such as macrophages, monocytes, neutrophils and neurons [37]. In addition, damaged or necrotic cells can passively release HMGB1 protein as well [38]. Tumor cells overexpressing HMGB1 have been reported to secrete it to the extracellular matrix in erythroleukemia, neuroblastoma and colon cancer cells $[39,40]$. This phenomenon usually occurs when tumor cells undergo necrosis or triggered by hypoxia, nutrient deprivation, absence of essential growth factors or application of conventional anticancer therapy [41, 42]. The released HMGB1 will trigger the chronic inflammatory response, promote tumor cell survival, invasion and neoangiogenesis through activation of intracellular signaling [43, 44]. As is known, the inflammatory tumor microenvironment can promote neoplastic transformation and support tumor growth, invasion and metastasis. Extracellular HMGB1, act as the prototypic damage associated molecular pattern molecule, can activate proinflammatory signaling pathways through conjunction with Toll-like receptors (TLRs) and receptor for advanced glycation end products (RAGE) to induce proinflammatory cytokine release. Inhibition of RAGEHMGB1 interaction has been proved to be effective in inhibiting tumor angiogenesis and growth, metastasis, migration and invasion of cancer cells [45-47]. Therefore, serum HMGB1 can be a potential powerful diagnostic and prognostic biomarker for patients with cancer. Among included studies, 4 researches [23, 24, 28, 31] showed that overexpressed serum HMGB1 was closely correlated with the advanced stage of cancer in pancreatic cancer, cervical carcinoma, and malignant pleural mesothelioma. The pooled estimate of HR for subgroup detected by ELISA in serum in our meta-analysis further confirmed its prediction for progression of patients with cancer. Meanwhile, Chung et al [23] and Sheng et al [31] respectively exhibited serum HMGB1 was a remarkable biomarker to predict pancreatic ductal adenocarcinoma and recurrent cervical squamous cell carcinomas with superior sensitivity or specificity compared to existing biomarkers.

In addition to the included studies, there were some other researches focusing on the correlation between HMGB1 expression and patient prognosis in osteosarcoma [48], ovarian cancer [49] and non-small cell lung cancer [50]. As the definite HRs with 95\% CIs were not described in these manuscripts, they were finally excluded from current meta-analysis. However, they also found that higher expression level of HMGB1 was significantly associated with a poorer prognosis. At the same time, Takeuchi et al [51] demonstrated that overexpression of RAGE, one of HMGB1's receptors, was associated with subsequent recurrence, lung metastasis, and poor survival in chondrosarcoma. 
A recent meta-analysis also showed higher expression of $\mathrm{C}-\mathrm{X}-\mathrm{C}$ chemokine receptor 4 (CXCR4), another HMGB1's receptor, indicated poorer prognosis in various types of cancer [2]. As a prognostic biomarker, we propose that HMGB1 has potential clinical applicability in certain aspects: (1) guide the therapy approaches selection and stratification; (2) monitor the response to a therapy for the decision whether it should be continued or not; (3) early alert to the possibility of cancer recurrence or metastasis. Furthermore, several recent researches discussed the combined application of HMGB1 with other existing biomarkers. HMGB1 has been demonstrated to work together with prostate specific antigen (PSA) for predicting biochemical recurrence in prostate cancer [20] or with squamous cell carcinoma antigen (SCCA) for early diagnosing recurrent cervical squamous cell carcinomas [32].

The identification of prognostic factors is critical for distinguishing high-risk patients who are good candidates for individualized treatment from others [52]. Our finding that HMGB1 overexpression is associated with poorer prognosis in cancer patients indicates this gene may have the potential to become a critical molecular target for tumor therapy. Jube et al [53] showed that treatment with HMGB1 inhibitors could prolong the survival of malignant mesothelioma xenograft mice, offering a preclinical proof-of-principle that antibody-mediated ablation of HMBG1 was sufficient to elicit antitumor therapeutic activity. At the same time, some studies have demonstrated that HMGB1 is constitutively expressed in the nucleus and perinuclear organelles of cancer cells with the active nucleo-cytoplasmic shuttling of HMGB1 existing [25]. As the functions of HMGB1 depend on the subcellular locations, its influence on tumor development and progression ought to be explained by different models. Future studies which focus on HMGB1 as a novel antitumor therapeutic approach should take it into consideration comprehensively.

Our study has several limitations. First, there were totally 2 specimen sources and 3 detection methods being involved within included studies. As a semi-quantitative measurement, IHC was adopted by majority of researches, however, only a few applied ELISA or qRT-PCR which were quantitative approaches in their studies. Among 11 studies using IHC, the cutoff values were based on the sum of the intensity and extent scores in 9 studies, whereas the cutoff points of rest 2 researches were solely determined by proportion of HMGB1 positive cells. Second, the HRs data of survival were extracted according to the univariate analysis in 2 included studies because the multivariate analysis was not performed. Third, there was a bias towards Asian patients because 11 of 15 studies were from China while only 3 from Japan and 1 from Korea. Lastly, the findings of this meta-analysis need to be confirmed by future complete and through studies in order to make a solid conclusion.

\section{MATERIALS AND METHODS}

\section{Literature search and article selection}

This meta-analysis was performed according to the Preferred Reporting Items for Systematic Reviews and Meta-Analyses (PRISMA) statement [54]. Literature searches of PubMed, Embase, and Web of Science databases were carried out in September 27th, 2015 using the following keywords: (high mobility group box 1 OR HMGB1) AND (prognosis OR survival). Search restrictions were set for the English language and human species. Electronic searches were supplemented by studying reference lists of the retrieved articles as well as relevant review articles. Each article was assessed for inclusion by T.W and W.Z independently and all disagreements were resolved via discussion.

\section{Inclusion and exclusion criteria}

The inclusion criteria for the studies were as follows: (1) evaluating the association between HMGB1 expression and prognosis of patients with any type of cancer; (2) reporting endpoints including OS and PFS; (3) displaying outcomes in the form of hazard ratio (HR) with $95 \%$ confidence interval (CI). The exclusion criteria included: (1) duplicated studies using the same population or overlapping database; (2) non-human research or articles in non-English; (3) reviews, letters, and comments.

\section{Evaluation of study quality}

The levels of evidence were estimated for all included studies with the Oxford Centre for Evidence Based Medicine criteria [55]. The methodological quality evaluation of the studies was conducted using the Newcastle-Ottawa Scale (NOS) for cohort study [56]. In addition, the specific quality assessment of prognosis studies was estimated according to the approach of Hayden et al [57]. The evaluated items with potential bias included study participation, study attrition, prognostic factor measurement, outcome measurement, confounding measurement and account, and analysis. The assessments were processed independently by two reviewers and the final decision was achieved by consensus.

\section{Statistical analysis}

In order to pool the OS or PFS of various included studies, heterogeneity between studies was assessed using the $\mathrm{Q}$ and $\mathrm{I}^{2}$ statistics: Significant heterogeneity was defined as $Q$ statistic $p$ value $<0.10$ or $\mathrm{I}^{2}$ value $>50 \%$. A fixed-effects model was used if there was no evidence of heterogeneity; otherwise, a random-effects model was used. Meta-analysis was performed using the pooled HR with $95 \% \mathrm{CI}$ as the risk estimate. An observed HR of $>1$ indicated poorer prognosis in patients with elevated 
HMGB1 expression. The HR was considered statistical superiority/inferiority between groups if the $95 \% \mathrm{CI}$ did not overlap with 1 . All $\mathrm{p}$ values were two-sided and statistical significance was set at $\mathrm{p}<0.05$. Stata software version 12.0 (Stata Corporation, College Station, Texas, USA) was used to conduct statistical analysis.

\section{CONCLUSIONS}

In summary, HMGB1 overexpression is associated with poorer prognosis in terms of OS and PFS in patients with various types of cancer, suggesting that it is a prognostic factor and potential biomarker for survival in cancer. Besides, HMGB1 presents as a potential antitumor target and further development of strategies against this receptor could be an attractive therapeutic approach.

\section{ACKNOWLEDGMENTS}

The study received funding from the Cultivation Foundation for Distinguished Postgraduate of Second Military Medical University, Shanghai, China. The funders had no role in study design, data collection and analysis, decision to publish, or preparation of the manuscript.

\section{CONFLICTS OF INTEREST}

No potential conflicts of interest were disclosed.

\section{REFERENCES}

1. All Cancers (excluding non-melanoma skin cancer) Estimated Incidence, Mortality and Prevalence Worldwide in 2012. World Health Organization. Website: http:// globocan.iarc.fr/Pages/fact_sheets_cancer.aspx. Accessed September 27, 2015.

2. Zhao H, Guo L, Zhao J, Weng H and Zhao B. CXCR4 over-expression and survival in cancer: a system review and meta-analysis. Oncotarget. 2015; 6:5022-5040. doi: 10.18632/oncotarget.3217.

3. Esposito A, Criscitiello C, Locatelli M, Milano M and Curigliano G. Liquid biopsies for solid tumors: Understanding tumor heterogeneity and real time monitoring of early resistance to targeted therapies. Pharmacology \& therapeutics. 2015.

4. Goodwin GH and Johns EW. Isolation and characterisation of two calf-thymus chromatin non-histone proteins with high contents of acidic and basic amino acids. European journal of biochemistry / FEBS. 1973; 40:215-219.

5. Wang H, Bloom O, Zhang M, Vishnubhakat JM, Ombrellino M, Che J, Frazier A, Yang H, Ivanova S, Borovikova L, Manogue KR, Faist E, Abraham E, Andersson J, Andersson U, Molina PE, et al. HMG-1 as a late mediator of endotoxin lethality in mice. Science. 1999; 285:248-251.
6. Kang R, Chen R, Zhang Q, Hou W, Wu S, Cao L, Huang J, Yu Y, Fan XG, Yan Z, Sun X, Wang H, Wang Q, Tsung A, Billiar TR, Zeh HJ, 3rd, et al. HMGB1 in health and disease. Molecular aspects of medicine. 2014; 40:1-116.

7. Thanos $\mathrm{D}$ and Maniatis $\mathrm{T}$. The high mobility group protein HMG I(Y) is required for NF-kappa B-dependent virus induction of the human IFN-beta gene. Cell. 1992; 71:777-789.

8. Baldassarre G, Battista S, Belletti B, Thakur S, Pentimalli F, Trapasso F, Fedele M, Pierantoni G, Croce CM and Fusco A. Negative regulation of BRCA1 gene expression by HMGA1 proteins accounts for the reduced BRCA1 protein levels in sporadic breast carcinoma. Molecular and cellular biology. 2003; 23:2225-2238.

9. Fashena SJ, Reeves R and Ruddle NH. A poly(dA-dT) upstream activating sequence binds high-mobility group I protein and contributes to lymphotoxin (tumor necrosis factor-beta) gene regulation. Molecular and cellular biology. 1992; 12:894-903.

10. Ellerman JE, Brown CK, de Vera M, Zeh HJ, Billiar T, Rubartelli A and Lotze MT. Masquerader: high mobility group box-1 and cancer. Clin Cancer Res. 2007; 13:2836-2848.

11. Lotze MT and DeMarco RA. Dealing with death: HMGB1 as a novel target for cancer therapy. Curr Opin Investig Drugs. 2003; 4:1405-1409.

12. Tang D, Kang R, Zeh HJ, 3rd and Lotze MT. High-mobility group box 1 and cancer. Biochimica et biophysica acta. 2010; 1799:131-140.

13. Kang R, Zhang Q, Zeh HJ, 3rd, Lotze MT and Tang D. HMGB1 in cancer: good, bad, or both? Clin Cancer Res. 2013; 19:4046-4057.

14. Akaike H, Kono K, Sugai H, Takahashi A, Mimura K, Kawaguchi Y and Fujii H. Expression of high mobility group box chromosomal protein-1 (HMGB-1) in gastric cancer. Anticancer research. 2007; 27:449-457.

15. He W, Tang B, Yang D, Li Y, Song W, Cheang T, Chen X, Chen L, Zhan W, Li W and He Y. Double-positive expression of high-mobility group box 1 and vascular endothelial growth factor $\mathrm{C}$ indicates a poorer prognosis in gastric cancer patients. World journal of surgical oncology. 2013; 11:161.

16. Zhang J, Zhang R, Lu WW, Zhu JS, Xia LQ, Lu YM and Chen NW. Clinical significance of hmgbl expression in human gastric cancer. International journal of immunopathology and pharmacology. 2014; 27:543-551.

17. Yao X, Zhao G, Yang H, Hong X, Bie L and Liu G. Overexpression of high-mobility group box 1 correlates with tumor progression and poor prognosis in human colorectal carcinoma. Journal of cancer research and clinical oncology. 2010; 136:677-684.

18. Peng RQ, Wu XJ, Ding Y, Li CY, Yu XJ, Zhang X, Pan ZZ, Wan DS, Zheng LM, Zeng YX and Zhang XS. Co-expression of nuclear and cytoplasmic HMGB1 is 
inversely associated with infiltration of CD45RO $+\mathrm{T}$ cells and prognosis in patients with stage IIIB colon cancer. BMC cancer. 2010; 10:496.

19. Soldevilla B, Diaz R, Silva J, Campos-Martin Y, Munoz C, Garcia V, Garcia JM, Pena C, Herrera M, Rodriguez M, Gomez I, Mohamed N, Marques MM, Bonilla F and Dominguez G. Prognostic impact of DeltaTAp73 isoform levels and their target genes in colon cancer patients. Clin Cancer Res. 2011; 17:6029-6039.

20. Ueda M, Takahashi Y, Shinden Y, Sakimura S, Hirata H, Uchi R, Takano Y, Kurashige J, Iguchi T, Eguchi H, Sugimachi K, Yamamoto H, Doki Y, Mori M and Mimori K. Prognostic significance of high mobility group box 1 (HMGB1) expression in patients with colorectal cancer. Anticancer research. 2014; 34:5357-5362.

21. Liu F, Zhang Y, Peng Z, Gao H, Xu L and Chen M. High expression of high mobility group box 1 (hmgb1) predicts poor prognosis for hepatocellular carcinoma after curative hepatectomy. Journal of translational medicine. 2012; 10:135.

22. Xiao J, Ding Y, Huang J, Li Q, Liu Y, Ni W, Zhang Y, Zhu Y, Chen L and Chen B. The association of HMGB1 gene with the prognosis of HCC. PloS one. 2014; 9:e89097.

23. Chung HW, Lim JB, Jang S, Lee KJ, Park KH and Song SY. Serum high mobility group box-1 is a powerful diagnostic and prognostic biomarker for pancreatic ductal adenocarcinoma. Cancer science. 2012; 103:1714-1721.

24. Wittwer C, Boeck S, Heinemann V, Haas M, Stieber P, Nagel D and Holdenrieder S. Circulating nucleosomes and immunogenic cell death markers HMGB1, sRAGE and DNAse in patients with advanced pancreatic cancer undergoing chemotherapy. International journal of cancer. 2013; 133:2619-2630.

25. Wu D, Ding Y, Wang S, Zhang Q and Liu L. Increased expression of high mobility group box 1 (HMGB1) is associated with progression and poor prognosis in human nasopharyngeal carcinoma. The Journal of pathology. 2008; 216:167-175.

26. Liu Y, Xie C, Zhang X, Huang D, Zhou X, Tan P, Qi L, $\mathrm{Hu}$ G, Tian Y and Qiu Y. Elevated expression of HMGB1 in squamous-cell carcinoma of the head and neck and its clinical significance. Eur J Cancer. 2010; 46:3007-3015.

27. Chuangui $\mathrm{C}$, Peng $\mathrm{T}$ and Zhentao $\mathrm{Y}$. The expression of high mobility group box 1 is associated with lymph node metastasis and poor prognosis in esophageal squamous cell carcinoma. Pathology oncology research : POR. 2012; 18:1021-1027.

28. Tabata C, Shibata E, Tabata R, Kanemura S, Mikami K, Nogi Y, Masachika E, Nishizaki T and Nakano T. Serum HMGB1 as a prognostic marker for malignant pleural mesothelioma. BMC cancer. 2013; 13:205.

29. Yang GL, Zhang LH, Bo JJ, Huo XJ, Chen HG, Cao M, Liu DM and Huang YR. Increased expression of HMGB1 is associated with poor prognosis in human bladder cancer. Journal of surgical oncology. 2012; 106:57-61.

30. Li T, Gui Y, Yuan T, Liao G, Bian C, Jiang Q, Huang S, Liu $\mathrm{B}$ and $\mathrm{Wu} \mathrm{D}$. Overexpression of high mobility group box 1 with poor prognosis in patients after radical prostatectomy. BJU international. 2012; 110:E1125-1130.

31. Sheng X, Du X, Zhang X, Li D, Lu C, Li Q, Ma Z, Song Q and Wang C. Clinical value of serum HMGB1 levels in early detection of recurrent squamous cell carcinoma of uterine cervix: comparison with serum SCCA, CYFRA21-1, and CEA levels. Croatian medical journal. 2009; 50:455-464.

32. Johann DJ, Jr., McGuigan MD, Patel AR, Tomov S, Ross S, Conrads TP, Veenstra TD, Fishman DA, Whiteley GR, Petricoin EF, 3rd and Liotta LA. Clinical proteomics and biomarker discovery. Annals of the New York Academy of Sciences. 2004; 1022:295-305.

33. Liu Y, Prasad R and Wilson SH. HMGB1: roles in base excision repair and related function. Biochimica et biophysica acta. 2010; 1799:119-130.

34. Hanahan D and Weinberg RA. Hallmarks of cancer: the next generation. Cell. 2011; 144:646-674.

35. Zhang L, Han J, Wu H, Liang X, Zhang J, Li J, Xie L, Xie Y, Sheng X and Yu J. The association of HMGB1 expression with clinicopathological significance and prognosis in hepatocellular carcinoma: a meta-analysis and literature review. PloS one. 2014; 9:e110626.

36. Lotze MT and Tracey KJ. High-mobility group box 1 protein (HMGB1): nuclear weapon in the immune arsenal. Nature reviews Immunology. 2005; 5:331-342.

37. Wu TY, Liu L, Zhang W, Zhang Y, Liu YZ, Shen XL, Gong $\mathrm{H}$, Yang YY, Bi XY, Jiang CL and Wang YX. High-mobility group box-1 was released actively and involved in LPS induced depressive-like behavior. Journal of psychiatric research. 2015; 64:99-106.

38. Klune JR, Dhupar R, Cardinal J, Billiar TR and Tsung A. HMGB1: endogenous danger signaling. Mol Med. 2008; 14:476-484.

39. Passalacqua M, Zicca A, Sparatore B, Patrone M, Melloni E and Pontremoli S. Secretion and binding of HMG1 protein to the external surface of the membrane are required for murine erythroleukemia cell differentiation. FEBS letters. 1997; 400:275-279.

40. Wahamaa H, Vallerskog T, Qin S, Lunderius C, LaRosa G, Andersson U and Harris HE. HMGB1-secreting capacity of multiple cell lineages revealed by a novel HMGB1 ELISPOT assay. Journal of leukocyte biology. 2007; 81:129-136.

41. Kepp O, Tesniere A, Schlemmer F, Michaud M, Senovilla L, Zitvogel L and Kroemer G. Immunogenic cell death modalities and their impact on cancer treatment. Apoptosis. 2009; 14:364-375.

42. Dong Xda E, Ito N, Lotze MT, Demarco RA, Popovic P, Shand SH, Watkins S, Winikoff S, Brown CK, Bartlett DL and Zeh HJ, 3rd. High mobility group box I (HMGB1) 
release from tumor cells after treatment: implications for development of targeted chemoimmunotherapy. J Immunother. 2007; 30:596-606.

43. Schiraldi M, Raucci A, Munoz LM, Livoti E, Celona B, Venereau E, Apuzzo T, De Marchis F, Pedotti M, Bachi A, Thelen M, Varani L, Mellado M, Proudfoot A, Bianchi ME and Uguccioni M. HMGB1 promotes recruitment of inflammatory cells to damaged tissues by forming a complex with CXCL12 and signaling via CXCR4. The Journal of experimental medicine. 2012; 209:551-563.

44. van Beijnum JR, Dings RP, van der Linden E, Zwaans BM, Ramaekers FC, Mayo KH and Griffioen AW. Gene expression of tumor angiogenesis dissected: specific targeting of colon cancer angiogenic vasculature. Blood. 2006; 108:2339-2348.

45. Taguchi A, Blood DC, del Toro G, Canet A, Lee DC, Qu W, Tanji N, Lu Y, Lalla E, Fu C, Hofmann MA, Kislinger $\mathrm{T}$, Ingram $\mathrm{M}$, Lu A, Tanaka $\mathrm{H}$, Hori $\mathrm{O}$, et al. Blockade of RAGE-amphoterin signalling suppresses tumour growth and metastases. Nature. 2000; 405:354-360.

46. Huttunen HJ, Fages C, Kuja-Panula J, Ridley AJ and Rauvala H. Receptor for advanced glycation end productsbinding $\mathrm{COOH}$-terminal motif of amphoterin inhibits invasive migration and metastasis. Cancer research. 2002; 62:4805-4811.

47. van Beijnum JR, Nowak-Sliwinska P, van den Boezem E, Hautvast P, Buurman WA and Griffioen AW. Tumor angiogenesis is enforced by autocrine regulation of highmobility group box 1. Oncogene. 2013; 32:363-374.

48. He J, Zhang P, Li Q, Zhou D and Liu P. Expression of high mobility group box 1 protein predicts a poorer prognosis for patients with osteosarcoma. Oncology letters. 2016; 11:293-298.

49. Paek J, Lee M, Nam EJ, Kim SW and Kim YT. Clinical impact of high mobility group box 1 protein in epithelial ovarian cancer. Archives of gynecology and obstetrics. 2016; 293:645-650.

50. Liu PL, Tsai JR, Hwang JJ, Chou SH, Cheng YJ, Lin FY, Chen YL, Hung CY, Chen WC, Chen YH and
Chong IW. High-mobility group box 1-mediated matrix metalloproteinase-9 expression in non-small cell lung cancer contributes to tumor cell invasiveness. American journal of respiratory cell and molecular biology. 2010; 43:530-538.

51. Takeuchi A, Yamamoto Y, Tsuneyama K, Cheng C, Yonekura $\mathrm{H}$, Watanabe T, Shimizu K, Tomita K, Yamamoto H and Tsuchiya H. Endogenous secretory receptor for advanced glycation endproducts as a novel prognostic marker in chondrosarcoma. Cancer. 2007; 109:2532-2540.

52. Wei Y and Niu B. Role of MALAT1 as a Prognostic Factor for Survival in Various Cancers: A Systematic Review of the Literature with Meta-Analysis. Disease markers. 2015; 2015:164635.

53. Jube S, Rivera ZS, Bianchi ME, Powers A, Wang E, Pagano I, Pass HI, Gaudino G, Carbone M and Yang H. Cancer cell secretion of the DAMP protein HMGB1 supports progression in malignant mesothelioma. Cancer research. 2012; 72:3290-3301.

54. Liberati A, Altman DG, Tetzlaff J, Mulrow C, Gotzsche PC, Ioannidis JP, Clarke M, Devereaux PJ, Kleijnen J and Moher D. The PRISMA statement for reporting systematic reviews and meta-analyses of studies that evaluate health care interventions: explanation and elaboration. PLoS medicine. 2009; 6:e1000100.

55. Phillips B, Ball C and Sackett D. Oxford Centre for Evidence-based Medicine-levels of evidence [Updated 2009]. Centre for Evidence-Based Medicine. Website: http://www.cebm.net/index.aspx?o=1025. Accessed September 27, 2015.

56. Wells G, Shea B and O'Connell D. The Newcastle-Ottawa Scale (NOS) for assessing the quality of nonrandomized studies in meta analyses. Ottawa Hospital Research Institute. Website: http:/www.ohri.ca/programs/clinical_ epidemiology/oxford.asp. Accessed September 27, 2015.

57. Hayden JA, Cote P and Bombardier C. Evaluation of the quality of prognosis studies in systematic reviews. Annals of internal medicine. 2006; 144:427-437. 